\title{
Modified atmosphere storage (mas) buah pisang
}

Wina Libyawati*, I Gede Eka Lesmana, A. Raynold, Hafidan Agustian, L. Mahardhika

Program Studi Teknik Mesin Universitas Pancasila, Srengseng Sawah, Jagakarsa, Jakarta Selatan 12640 Telp. (021) 7864730 Ext.105 Fax. (021) 7270128, 7272290,

*Email : wina@univpancasila.ac.id

\section{ARTICLE INFO}

Article History:

Received February 2017

Accepted October 2017

Available online 30 December 2017

Keywords:

MAS

Bananas,

Sparger,

TKE,

Gas mixing

In cooperation with SNMI XI 2017

Special Edition

\section{ABSTRACT}

Healthy life style based on natural food consumption, has been implemented by the society to increase health quality. Minimally processed technology is used to slow down food decay time in the storage room. Minimally processed techology is consist of Controlled Atmosphere Storage (CAS), Modified Atmosphere Storage (MAS), Freeze Driying, and blansir. MAS is food storage technology by conditioning the air composition (especially oxygen level). Banana is an object of MAS implementation, due to its all session fruit and shorter life time. Previous MAS studies used long bean as the object and managed to improve the life time until 15 days. The purpose of this study is to implement MAS to lengthen banana life time. MAS design use Ulrich Eppinger method. Simulation of Turbulance Kinetic Energy (TKE) in the sparger and MAS installation use ANSYS 16.2. The experimental to test sparger and installation is conducted for 6 hours for the sparger and 24 hours for the installation. Afterward the correlation between parameter is calculated by using least square method. The outcome of this research is MAS for banana in order to be used by SME with capacity of $4.77 \mathrm{~m}^{3}$, mixture time is 24 hours, TKE number in the sparger is $582.6448 \mathrm{~J} / \mathrm{kg}$, TKE number in the installation is $715.6 \mathrm{~J} / \mathrm{kg}$, oxygen level in the sparger is $5.7 \%$, oxygen level in MAS installation is $8.5 \%$, glucose of banana located in the storage room is $9.5 \%$, and banana life time able to achiave 14 days.

\section{PENDAHULUAN}

Pola hidup sehat melalui konsumsi makan bergizi alami tanpa pengawet, telah disadari oleh masyarakat secara luas. Makanan tanpa pengawet memiliki nilai gizi tinggi akan tetapi memiliki umur simpan yang rendah. Umur simpan rendah dari makanan tanpa pengawet, dapat diatasi dengan menjaga kondisi ruang simpan makanan tersebut. Pengkondisian ruang simpan tanpa menyentuh makanan yang disimpan. merupakan salah satu alternatif untuk pengawetan tanpa merusak kandungan gizi di makanan.

Perkembangan teknologi pengkondisian ruang simpan tanpa melibatkan makanan diantaranya adalah teknologi vakum (Sidik, 2000), teknologi Controlled Atmosphere Storage (CAS) (Kader dkk., 2004), pendinginan (Santoso, 
2006), pengkondisian keseluruhan komposisi udara di ruang simpan, dan teknologi Modified Atmosphere Store (MAS). Teknologi vakum dipergunakan pada kemasan makanan dengan prinsip sistem terisolasi, sehingga kadar oksigen berada di bawah $2 \%$. Hasil penerapan teknologi vakum menunjukkan padi mampu diawetkan dengan media perendaman dalam kurun waktu 14 hari, akan tetapi merubah kandungan gizi (Sidik, 2000). CAS menerapkan prinsip sistem terisolasi akan tetapi mempergunakan tambahan gas untuk mengkondisikan keseluruhan komponen udara, capaian kadar oksigen di ruang simpan CAS adalah bawah $8 \%$, dan dapat mengendalikan suhu ruang penyimpanan sampai dengan dibawah $10^{\circ} \mathrm{C}$. Sehingga dapat memperpanjang umur simpan buah khususnya pisang sampai dengan 42 minggu. Perkembangan teknologi CAS menunjukkan pisang mampu bertahan dalam kurun waktu 42 minggu dalam ruang penyimpanan, akan tetapi kandungan gizi mengalami perubahan dan proses pengkondisian ruang simpan harus dilakukan secara berkesinambungan selama waktu penyimpanan (Badran, 1969). Metode pendingingan dilakukan dengan menurunkan suhu di ruang simpan. Lemari es merupakan contoh dari penerapan metode pendinginan. Lemari es mampu memperpanjang umur simpan dari makanan, akan tetapi merubah kandungan gizi serta memicu timbulnya pertumbuhan bakteri dan jamur yang berbahaya (Santoso, 2006). Pengkondisian keseluruhan komponen udara di ruang simpan dilakuan dengan memodifikasi kadar oksigen dan/atau karbon dioksida di ruang simpan. Metode pengkondisian keseluruhan komponen udara tersebut mampu memperpanjang umur simpan akan tetapi proses pengkondisian membutuhkan sensor gas untuk keseluruhan komponen udara. MAS telah diterapkan untuk penyimpanan nangka dengan cara menyuntikkan gas karbon dioksida murni ke dalam ruang penyimpanan, sehingga di ruang penyimpanan berada di bawah $5^{\circ} \mathrm{C}$, sehingga memperpanjang umur simpan sampai dengan 16 hari, dan proses pengawetan tidak harus dilakukan secara berkesinambungan (Sudiari dkk., 1998).

Perbandingan hasil pengkondisian ruang simpan di atas menunjukkan MAS memiliki keunggulan proses pengkondisian ruang simpan tidak berkesinambungan dan makanan tidak mengalami perubahan kandungan gizi. Kebijakan pemerintah untuk meningkatkan ketahanan pangan tergambar dalam Peraturan Presiden Nomor 22 Tahun 2009 tentang Kebijakan Percepatan Penganekaragaman Konsumsi Pangan Berbasis Sumber Daya Lokal. Kebijakan tersebut mendorong pemanfaatan budi daya sumber daya hayati di lahan terbatas seperti pekarangan rumah dan kebun skala kecil menengah. Keunggulan teknologi MAS dan perkembangan kebijakan pemerintah mendukung pengembangan teknologi MAS sehingga dapat dimanfaatkan untuk Usaha Mikro Kecil dan Menengah (UMKM).

Rancangan bangun teknologi MAS dilakukan dengan menerapkan prinsip-prinsip perancangan oleh Ulrich dan Eppinger (Ulrich et all., 1995). Alat penyuntik yang digunakan untuk mencampur karbon dioksida dengan udara adalah sparger (Arianto dkk., 2009). Proses manufaktur dari teknologi MAS untuk UMKM dilakukan setelah dilakukan simulasi hasil pencampuran antara udara dengan oksigen di ruang pencampuran dan ruang simpan makanan menggunakan ANSYS 16.2. Eksperimental dilakukan untuk melihat dampak hasil pencampuran di ruang pencampuran dan ruang simpan. Hasil uji eksperimen diolah dengan menggunakan metode Least Square.

\section{METODE PENELITIAN}

Tahapan penelitian untuk dapat menghasilkan MAS buah pisang untuk UMKM terdiri dari tahap perancangan, tahap pembuatan, dan tahap uji. Tahap perancangan terdiri dari perancangan sparger dan instalasi MAS. Tahap uji terdiri dari uji fungsional dan uji kinerja. Tahapan penelitian terangkum pada Gambar 1 .

\section{RANCANG BANGUN MAS BUAH PISANG Rancangan MAS Buah Pisang} Rancangan MAS buah pisang dengan membuat konsep produk sesuai dengan perkembangan teknologi MAS di pasaran dan paten yang telah ada. Konsep dibuat dengan melalukan pendekatan fungsional dan pendekatan struktur dilakukan dengan terlebih dahulu membuat diagram fungsi dan subfungsi. 

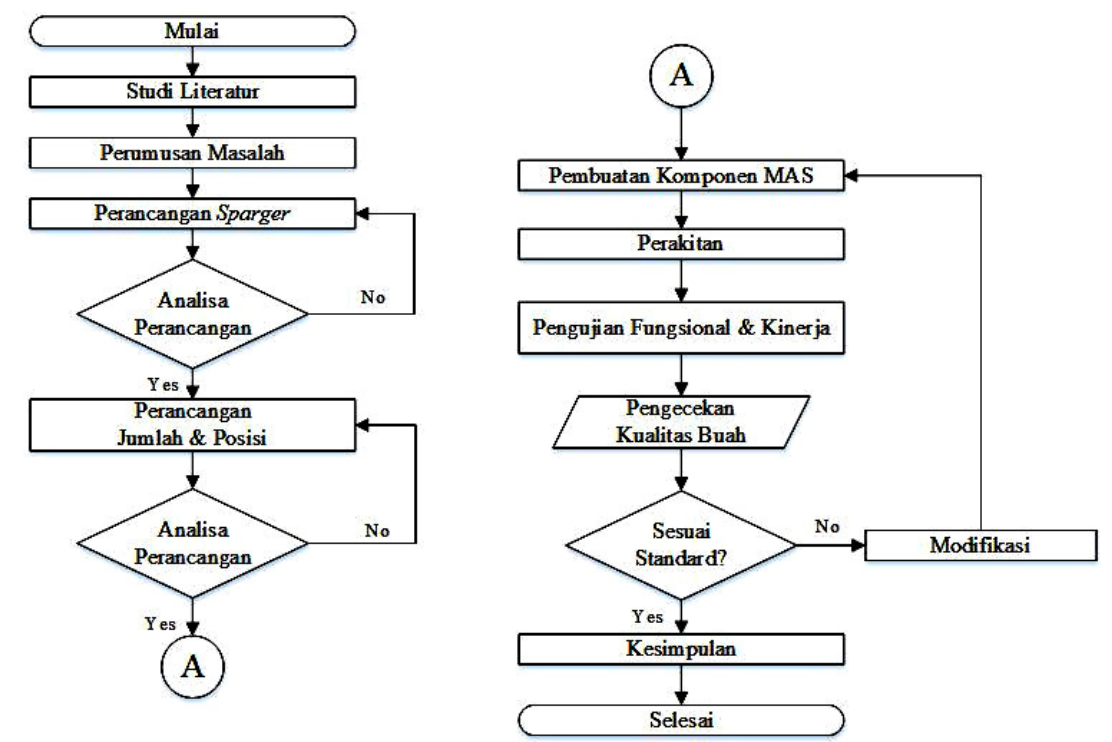

Gambar 1. Metodologi penelitian

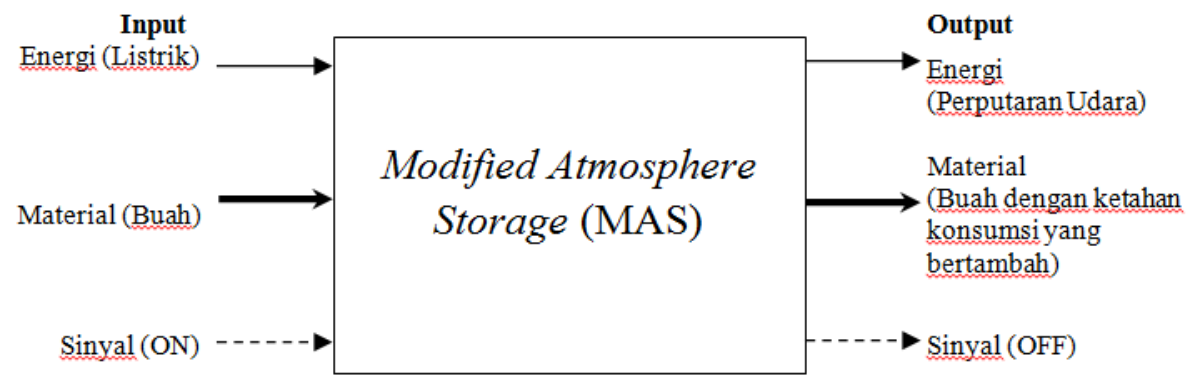

Gambar 2. Diagram fungsi MAS

Gambar 2 menunjukkan komponen fungsi utama dari MAS. Karbon diosida murni dicampur dengan udara di ruang simpan menggunakan sparger dan hasil pencampuran disirkulasikan dengan sebuah kipas di bagian sisi dari ruang simpan. Ruang simpan harus dikondisikan kedap udara sehingga tidak ada pengaruh dari kondisi udara di ruang simpan. Rincian dari keseluruhan komponen pada MAS terangkum pada Gambar 3.

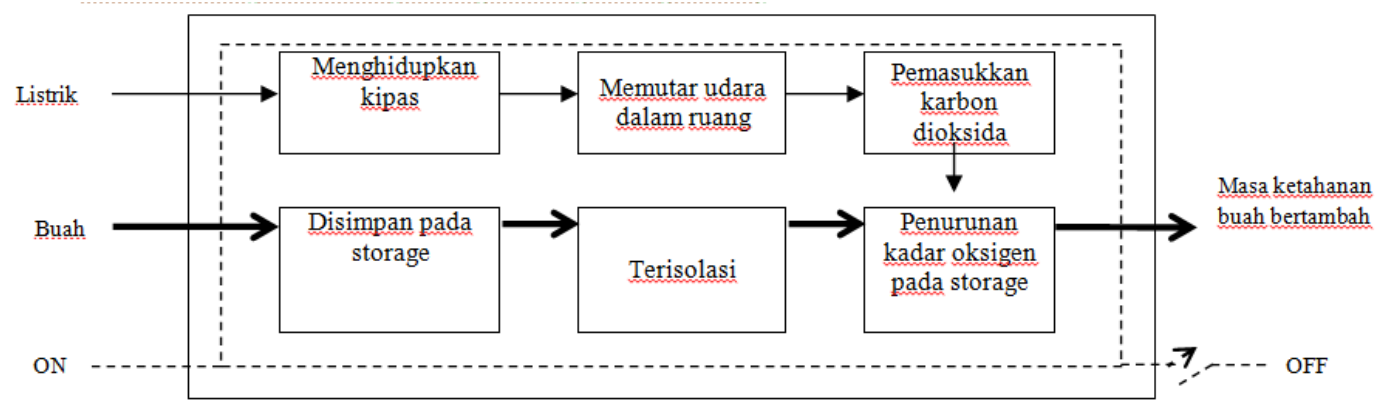

Gambar 3. Diagram sub fungsi MAS

Gambar 2 menunjukan terdapat 3 (tiga) komponen utama di MAS yaitu sirkulasi udara, https://doi.org/10.29303/dtm.v7i2.159 sparger, dan ruang simpan. Sirkulasi udara dilakukan oleh kipas. Penyuntik dan ruang 
campur karbon dioksida dilakukan oleh sparger. Ruang simpan berfungsi sebagai rangka struktur dan ruang penyimpanan. Setelah keseluruhan tahap perancangan dilakukan maka dibuatlah gambar kerja dan model CAD. Gambar kerja dan model CAD dibuat dengan bantuan Pro Eng. Model CAD MAS seperti Gambar 4.

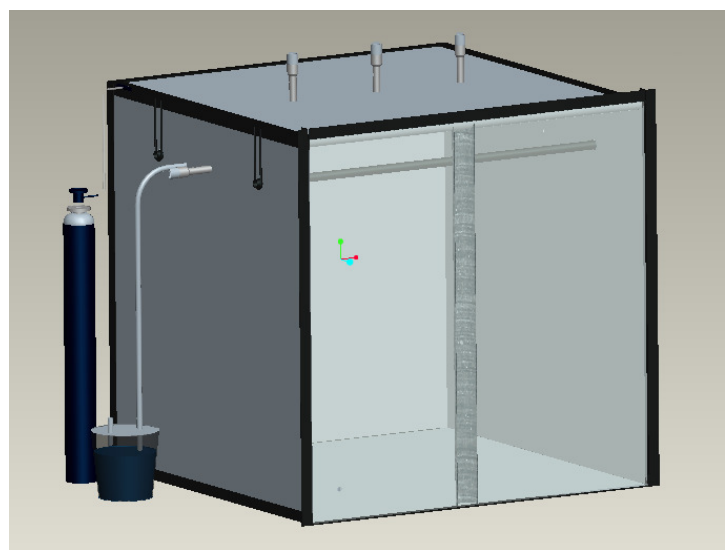

Gambar 4. Rancangan MAS

Rancangan MAS pada gambar 3 memiliki spesifikasi dimensi ruang $1720 \mathrm{~mm} \mathrm{x}$ $1720 \mathrm{~mm} \times 1720 \mathrm{~mm}$ atau equivalen dengan 10 tandan buah pisang, sparger sejumlah 6 (enam) buah mampu menyuntikkan karbondioksida dengan debit 5 liter/menit, serta rangka memiliki tegangan maksimum $79,4 \mathrm{~N}$ setelah dilakukan simulasi tegangan. Estimasi waktu pembuatan keseluruhan komponen 5,55 jam dan biaya proses manufaktur Rp. 112.431,55. Nilai ekonomis dari MAS adalah Rp. 6.000.000,00.

Tingkat homogenitas campuran antara karbon dioksida dengan udara dinilai dari

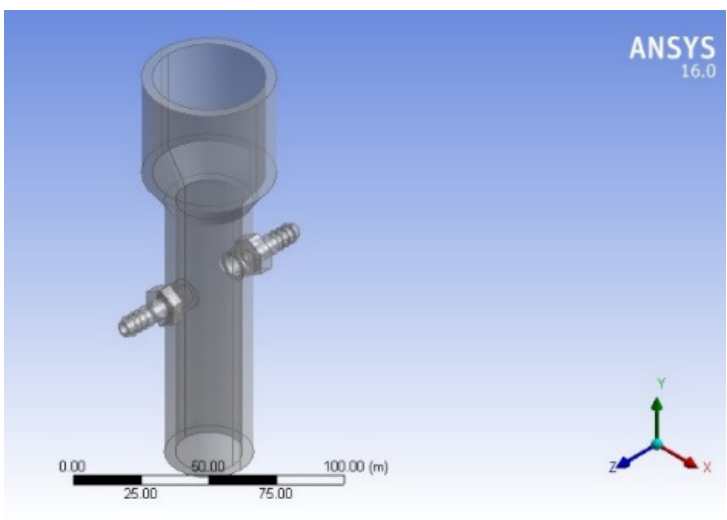

(a) Rancangan Sparger

Gambar 5. (a) Rancangan sparger
Turbulance Kinetic Energy (TKE) pada sparger dan ruang penyimpanan. Rancangan sparger merupakan hasil sambungan dua reducer dengan diameter dalam $19 \mathrm{~mm}$ dan luar 44,4 $\mathrm{mm}$, panjang diameter $38 \mathrm{~mm}$, serta dimensi sudut keluar $180^{\circ}$. Simulasi homogenitas di dalam sparger dilakukan dengan menggunakan ANSYS fluent 16.2. Asumsi sewaktu pemodelan homogenitas adalah tekanan udara yang masuk pada lubang masuk yaitu $101325 \mathrm{~Pa}$ dan kecepatan gas pada lubang masuk karbon yaitu 0,008353 $\mathrm{m} / \mathrm{s}$. Hasil analisis homogenitas di dalam sparger terlihat pada Gambar 5.

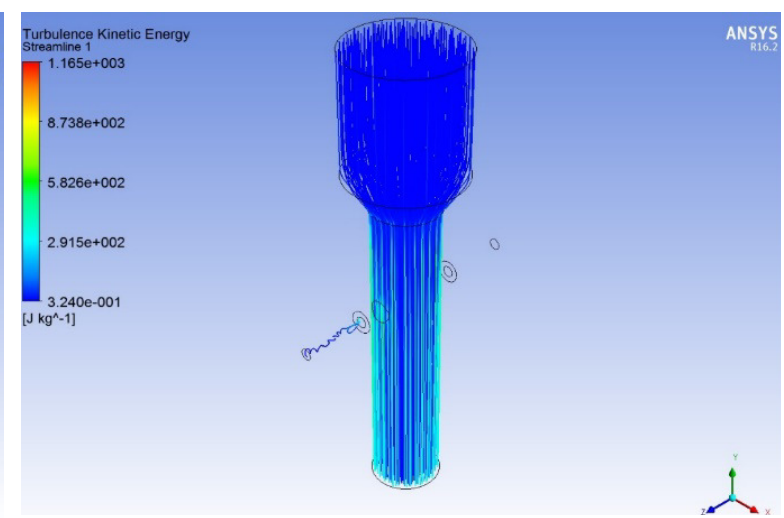

(b) Simulasi TKE di Sparger
Tingkat homigenitas di ruang simpan dengan jumlah sparger 6 (enam) buah dan posisi seperti terlihat pada Gambar 6. Hasil simulasi dengan menggunakan ANSYS adalah pada ruang TKE dengan nilai maksimal 1431,6 J/kg dan nilai minimum $0.0260 \mathrm{~J} / \mathrm{kg}$ dengan rata-rata https://doi.org/10.29303/dtm.v7i2.159
$715,60 \mathrm{~J} / \mathrm{kg}$, serta memiliki tekanan sebesar 264391 Pa. Nilai TKE pada Gambar 6.a menunjukkan terjadinya turbulensi dan homogenitas tercapai pada seluruh sisi dari ruang penyimpanan. Tekanan yang terjadi pada 
Gambar 6.b menunjukkan tekanan yang terjadi

masih di dalam ambang batas.

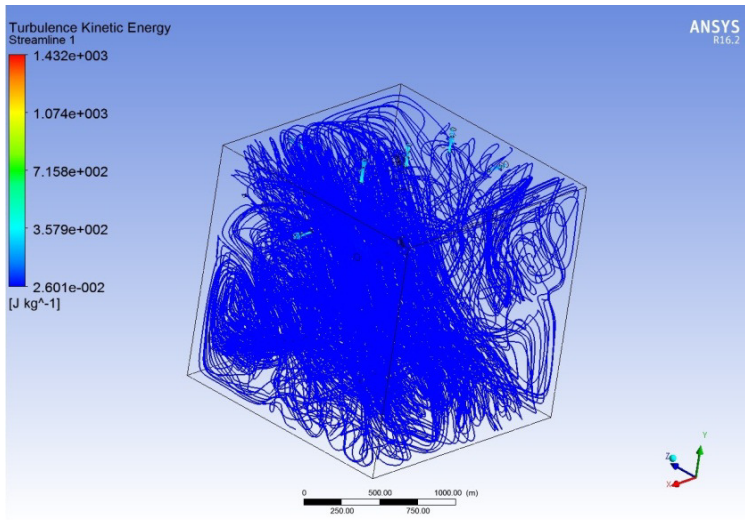

(a) Simulasi TKE

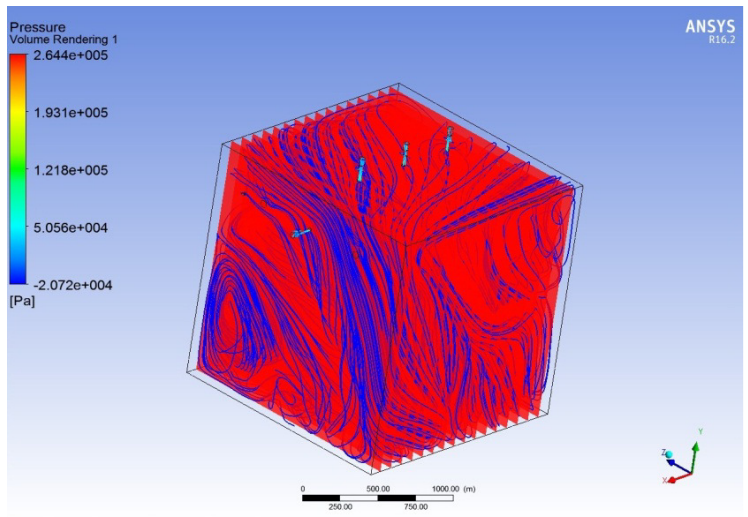

(b) Simulasi Tekanan

Gambar 6. Simulasi TKE dan tekanan di ruang penyimpanan

\section{Pembuatan MAS Buah Pisang}

Pembuatan MAS buah pisang difokuskan kepada pembuatan ruang simpan dan sparger. Pembuatan ruang simpan mempergunakan las PVC dan pengeboran. Tahapan pembuatan meliputi proses pemotongan, proses las PVC dan proses pengeboran. Tahapan pembuatan dibuat berdasarkan OPC (Operational Procedure Chart). Perwujudan dari MAS buah pisang terlihat pada Gambar 7. Kendala yang terjadi saat proses pembuatan adalah kesulitan untuk membuat ruang simpan kedap udara karena adanya akses keluar masuk untuk suplai buah pisang.
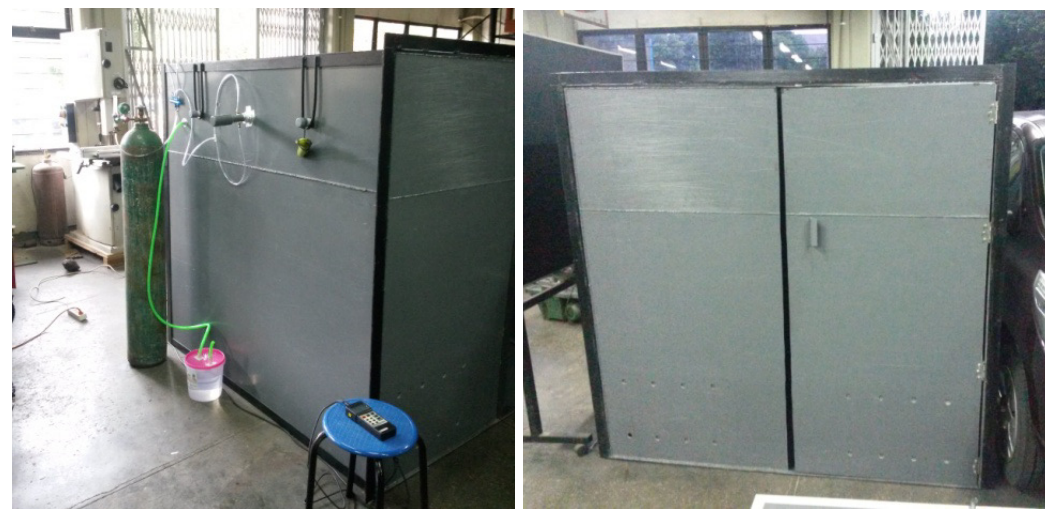

Gambar 7. MAS buah pisang

\section{HASIL DAN PEMBAHASAN}

\section{Spesifikasi MAS}

MAS buah pisang yang dihasilkan dari hasil rancangan dan pembuatan memiliki spesifikasi teknis seperti terangkum pada Tabel1.

Tabel 1 Spesifikasi MAS buah pisang

\begin{tabular}{clc}
\hline No & \multicolumn{1}{c}{ Parameter } & Besaran/Jenis \\
\hline 1 & Panjang & $1720 \mathrm{~mm}$ \\
2 & Lebar & $1720 \mathrm{~mm}$ \\
3 & Tinggi & $1720 \mathrm{~mm}$ \\
4 & Kapasitas ruang & $4,77 \mathrm{~m}^{3}$ \\
& simpan & PVC \\
5 & Material & .
\end{tabular}

https://doi.org/10.29303/dtm.v7i2.159

\begin{tabular}{|c|c|c|}
\hline 6 & Jenis sparger & Venturi \\
\hline 7 & $\begin{array}{l}\text { Waktu penurunan } \\
\text { kadar oksigen per } \\
\text { siklus }\end{array}$ & 24 jam \\
\hline 8 & $\begin{array}{l}\text { Capaian } \\
\text { oksigen }\end{array}$ & $8,5 \%$ \\
\hline & Waktu penyimpanan & 14 hari \\
\hline
\end{tabular}

\section{Kinerja Sparger}

Sparger jenis venturi sebelum ditempatkan pada MAS diuji dengan melihat hubungan antara waktu pemasukkan gas karbon dioksida dengan tingkat kandungan gas karbon dioksida dan oksigen di dalam sparger. Pelaksanaan uji 
dilakukan selama 6 jam, dengan mencampur karbon dioksida dengan udara di simulator ruang penyimpanan, untuk kemudian setelah kadar oksigen berada di bawah 10\% pemasukan karbon dioksida dihentikan. Hasil uji terangkum pada Gambar 8.

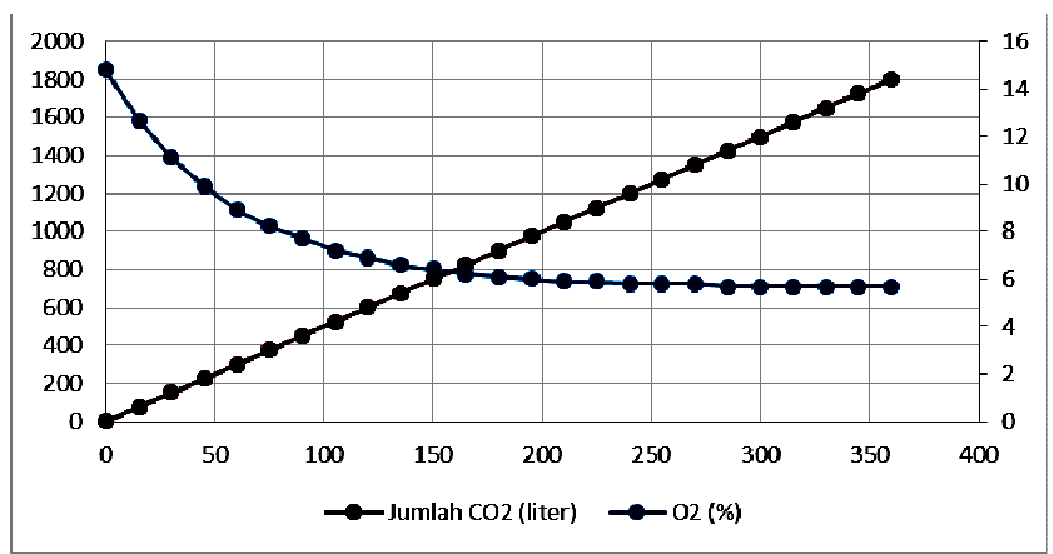

Gambar 8. Hubungan antara waktu pemasukan $\mathrm{CO}_{2}$ dengan kadar $\mathrm{CO}_{2}$ dan $\mathrm{O}_{2}$ di Sparger

Gambar 8 menunjukkan di sumbu horisontal sebagai waktu pemasukan dalam satuan menit, sumbu vertikal sisi kiri adalah kandungan $\mathrm{CO}_{2}$ dalam satuan liter, dan sumbu vertikal sisi kanan adalah prosentase kandungan $\mathrm{O}_{2}$. Terjadi penurunan kadar $\mathrm{O}_{2}$ setelah masukknya $\mathrm{CO}_{2}$ selama 6 jam dengan pengambilan data setiap 15 menit, dengan capaian kadar oksigen terendah adalah $5.7 \%$. Metode least square dipergunakan untuk melihat tingkat pengaruh dari penambahan $\mathrm{CO}_{2}$ terhadap penurunan $\mathrm{O}_{2}$. Gambar 9a menunjukkan pada menit $0-180$ mengalami penurunan $\mathrm{O}_{2}$ dengan $r^{2}=0,9268$. Gambar 9b menunjukkan pada menit 180 - 360 mengalami penurunan $\mathrm{O}_{2}$ yang kurang signifikan dengan penurunan $r^{2}=0,8836$, sedangkan penurunan $\mathrm{O}_{2}$ secara keseluruhan $r=-0,8082$ dan $r^{2}=0,6531$. Terlihat $\mathrm{CO}_{2}$ mempengaruhi penurunan $\mathrm{O}_{2}$ sebesar $65,31 \%$, sementara penurunan $\mathrm{O}_{2}$ sebesar $34,69 \%$ dipengaruhi oleh faktor lainnya.

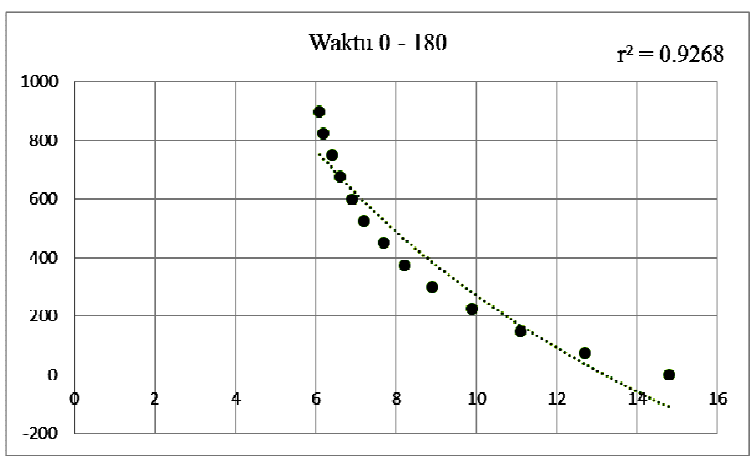

(a) 0-180 menit

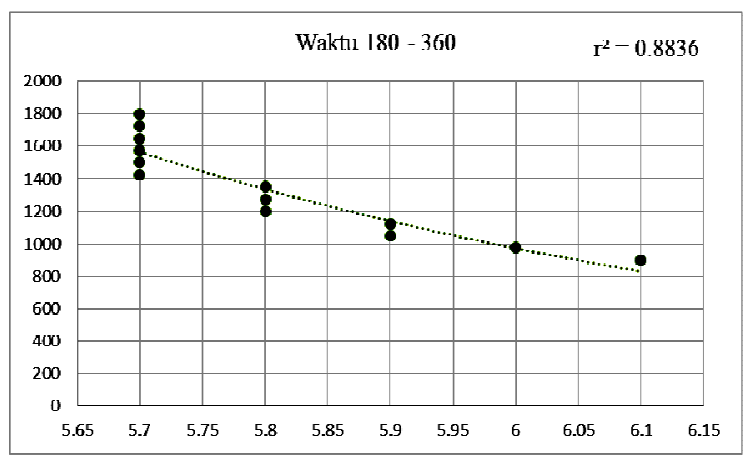

(b) $180-360$ menit

Gambar 9. Pendekatan hubungan antara $\mathrm{CO}_{2}$ dengan $\mathrm{O}_{2}$ di sparger

\section{Kinerja MAS}

Kinerja MAS buah pisang dinilai sama dengan sparger yaitu dari hubungan antara kandungan karbon dioksida dengan oksigen di ruang simpan. Uji kinerja dilakukan selama 24 jam dengan pengambilan data per jam. Gambar 10 merangkum data hasil uji kinerja MAS, dimana di sumbu horisontal adalah waktu pemasukan karbon dioksida dalam satuan jam, sumbu vertical sisi kiri adalah jumlah $\mathrm{CO}_{2}$ dalam satuan liter, dan sumbu vertical sisi kanan adalah kadar oksigen dalam prosentase. Penurunan kadar $\mathrm{O}_{2}$ setelah disuntik $\mathrm{CO}_{2}$ selama 24 jam mencapai $8,5 \%$. 


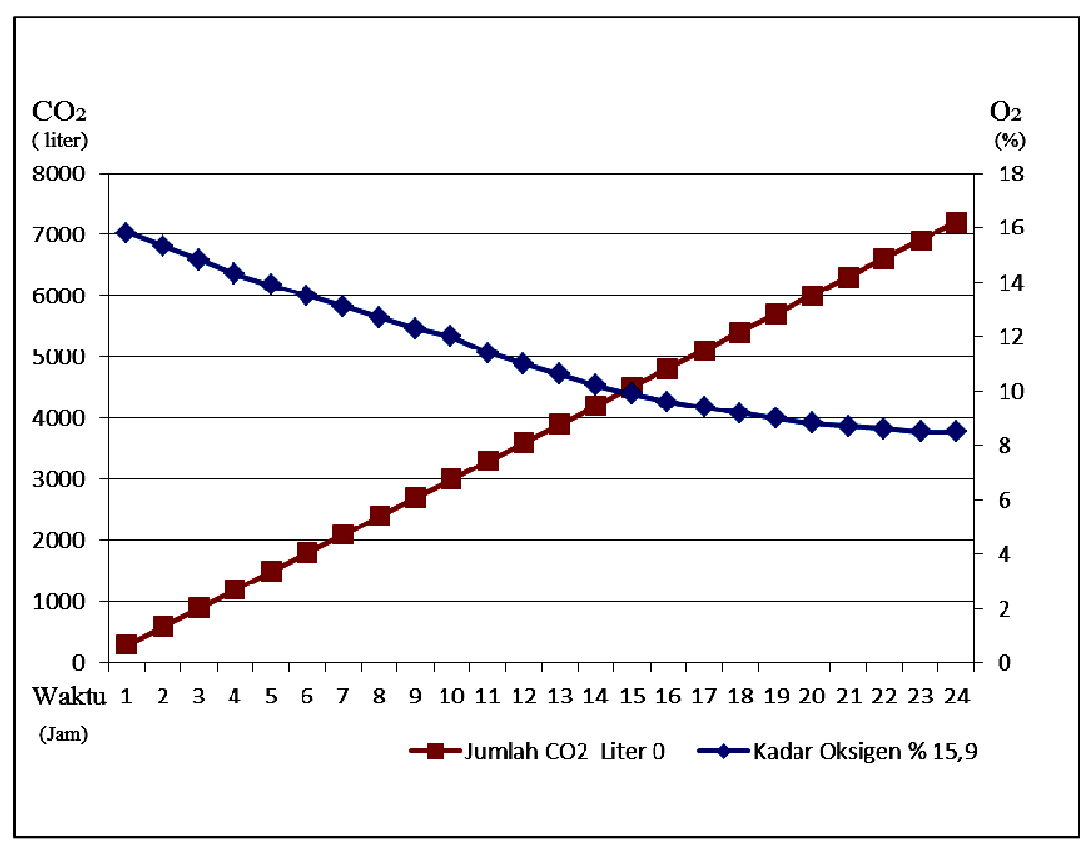

Gambar 10. Hubungan waktu pemasukan $\mathrm{CO}_{2}$ dengan kadar $\mathrm{CO}_{2} \& \mathrm{O}_{2}$ di ruang penyimpanan MAS

Metode least square kembali diterapkan untuk memperoleh tingkat pengaruh dari penambahan $\mathrm{CO}_{2}$ terhadap penurunan $\mathrm{O}_{2}$. Gambar 11a menunjukkan untuk waktu 0 - 18 jam mengalami penurunan $\mathrm{O}_{2}$ yang signifikan dengan $r^{2}=0,9965$, sementara Gambar 11b

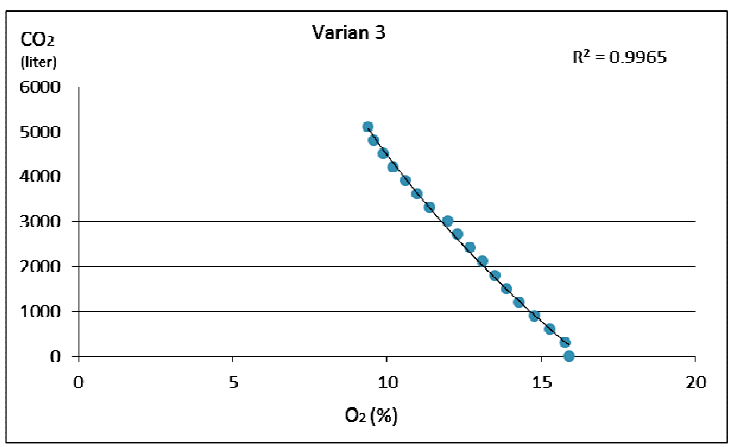

(a) 0-18 jam menunjukkan untuk waktu $18-24$ jam mengalami penurunan $\mathrm{O}_{2}$ yang tidak signifikan dengan $r^{2}=0,962$. $r=-0,9842$. Rerata penurunan dengan $r^{2}=0,96859$. Dimana $\mathrm{CO}_{2}$ mempengaruhi penurunan kadar $\mathrm{O}_{2}$ sebesar $96,859 \%$.

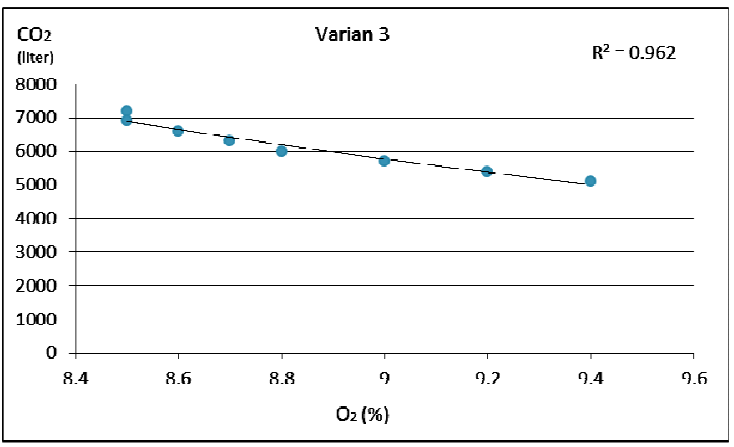

(b) 18-24 jam

Gambar 11. Pendekatan hubungan antara $\mathrm{CO}_{2}$ dengan $\mathrm{O}_{2}$ di MAS

Pengujian kadar glukosa dilakukan dengan uji kadar glukosa antar pisang yang disimpan dalam MAS dengan pisang yang diletakkan dalam kondisi ruang. Hasil uji kadar glukosa untuk pisang yang disimpan dalam MAS adalah $5,33 \%$, sementara yang diletakkan dalam kondisi ruang adalah $30 \%$. Standar tingkat kematangan buah pisang adalah memiliki kadar glukosa $15 \%$ $-20 \%$.

https://doi.org/10.29303/dtm.v7i2.159

\section{KESIMPULAN}

Teknologi MAS dengan kapasitas 4,77 $\mathrm{m}^{3}$ dengan waktu penurunan kadar oksigen sampai di bawah $10 \%$ adalah 24 jam dan nilai jual sebesar Rp. 6.000.000,00 mampu memperpanjang umur simpan pisang sampai dengan 14 hari dengan kadar glukosa sebesar $5,33 \%$. Teknologi MAS buah pisang dapat diterapkan di UMKM karena metode pengoperasian yang mudah dan nilai investasi 
yang ekonomis. MAS buah pisang belum mempertimbangkan monitoring perubahan kondisi ruang simpan dan buah, penggunaan gas $\mathrm{CO}_{2}$ murni dapat digantikan dengan gas buang dari genset apabila disertakan pengurai gas buang.

\section{DAFTAR PUSTAKA}

Arianto, Arifin, Syaiful, 2009, Perancangan sistem pengendalian level deaerator menggunakan fuzzy gain scheduling, PT. PETROWIDADA. Department of Engineering Physics, FTI, ITS, Surabaya.

Badran A.M.,1969, Controlled atmosphere storage of green bananas, United Fruit Company, U.S., 99-154.

Kader, Adel A., 2004, Controlled atmosphere storage.
Sidik M., 2000, The quality changes of rice stored under vacuum conditions, The National Logistic Agency (BULOG) and Presedent at ASEAN

Santoso, 2006,Teknologi pengawetan bahan segar, Malang.

Sudiari, Ni Made, Sutrisno, 1998, Pengkajian karakteristik penyimpanan produk minimally processed buah nangka.

Ulrich K.T., Eppinger S.D.,1995, Product design and development, McGraw-Hill, Inc., New York. 